\title{
THE MORPHOLOGICAL PROCESS OF ENGLISH DERIVATIONAL ADJECTIVE
}

\author{
Ida Ayu Gede Candra Dewi Laksemi \\ Fakultas Ilmu Sosial dan Ilmu Politik \\ e-mail: Chandra.laksemi@gmail.com
}

\begin{abstract}
This study is purposed to find out the morphological process of English derivational adjective found in novel"A Doctor - Nurse Encounter". It is aimed to find out kinds of derived adjective, analysis the morphological process of derivational, and analysis the process of derived adjective. Derivational morpheme has function to form a new word either by changing the meaning of the base to which they are attached or by changing the word class. Derivation is concerned with the formation of new lexemes by affixation. This research uses qualitative method. In presenting the analyzed data, the combination method of formal and informal are used. The formal data means that the data is presented by symbols and informal method presents the data by explaining it in words and paragraph. The collected data are analyzed descriptively by applying the theories adopted, such as morphological theory from Katamba (1993) and McCharty (2002). Finally this writing concludes that there are 21 affixes derived adjective in novel " A Doctor - Nurse Encounter". Those are un-, dis-, in-, -able, -al, -ous,-ful,-ed,-ing, -y, -ish, -ive, -ly, -ary, -less, -est, -ent, -en, -ar,-er,-ic. The most dominant affixes derived adjective in the novel " A Doctor - Nurse Encounter" is suffixes -ed which reaches 69 numbers.
\end{abstract}

Keywords : Derivational Adjective , Affixes, Prefixes, Suffixes

\begin{abstract}
Abstrak - Penelitian ini bertujuan untuk mengetahui proses morfologi kata turunan bahasa Inggris yang ditemukan dalam novel "A Doctor - NurseEncounter". Hal ini bertujuan untuk mengetahui jenis-jenis kata sifat turunan, menganalisis proses morfologi kata turunan, dan menganalisis proses kata sifat turunan. Morfem berfungsi untuk membentuk kata baru baik dengan mengubah arti dari dasar yang mereka lampirkan atau dengan mengubah kelas kata. Derivasi berkaitan dengan pembentukan leksem baru oleh afiksasi. Penelitian ini menggunakan metode kualitatif. Dalam menyajikan data yang dianalisis, metode kombinasi formal dan informal digunakan. Data formal berarti bahwa data disajikan oleh simbol dan metode informal menyajikan data dengan menjelaskannya dalam kata-kata dan paragraf. Data yang terkumpul dianalisis secara deskriptif dengan menerapkan teori yang diadopsi, seperti teori morfologi dari Katamba (1993) dan McCharty (2002). Akhirnya tulisan ini menyimpulkan bahwa ada 21 afiks kata sifat dalam novel "A Doctor - NurseEncounter". Mereka adalah un-, dish-, in-, -able, -al,-ous, -ful, -ed,-ing, $-y$, -ish, -ive, -ly, -ary, -less, -est, -ber, -en, -ar, -er, -ic. Afiks yang paling dominan berasal kata sifat dalam novel "A Doctor - NurseEncounter" adalah sufiks -ed yang mencapai 69 angka.
\end{abstract}

Kata kunci: kata sifat derivasional, afiks, prefix, sufiks

\section{INTRODUCTION \\ 1.1 Background of the Study}

Language consists of sentences that bring information or message. A sentence is the largest unit of language structure treated in traditional grammar which is having a subject and predicate. A sentence consists of words. Word is a free form which can stand by itself. It is composed of one or more morphemes. The study of the word is done at the level morphology. Morphology is a field which specializes in breaking up words into the smallest syntactic units called morphemes (Aitchinson,1992:53). According 
to McCharty (2002:16) morpheme is the smallest parts of words. A morpheme can be defined as the minimal linguistic sign, a grammatical unit that is an arbitrary union of sound and a meaning and that cannot be further analyze. In an extreme case, a morpheme may occur in a single word. A word may consist of the two types of morpheme : free morpheme and bound morpheme (Aitchinson,1992:53). Free morpheme is a morpheme which stands independently. Bound morpheme is a morpheme which is attached to the free morpheme. Bound morpheme can divided into two types : inflection and derivation. Inflectional morpheme expresses grammatical information that gives the language to choose and modify a word's tense, number, aspect or person. It cannot change the meaning and the word classes when they are attached. On the other hand, derivational morpheme changes the basic meaning of a word and the word class. The bound morpheme : inflection and derivational are normally referred to affixes. Affix is a morpheme which only occurs when it is attached to other free morpheme. Affix can divided into three types, those are prefix, suffix, and infix. Prefix is an affix attached before a word (free morpheme). Suffix is an affix attached after free morpheme. Infix is an affix into a free morpheme An affix can change the meaning and word classes, whether it changes the verb into adjectives , noun, becomes verb, adjective becomes verb and so on. There are a lot of word that have different meaning and word class from the basic word (free morpheme).

\subsection{Problems of the Study}

To know the affixes use to derive adjective in the short story " The Door In The Wall" there are two problems that the researcher wants to point out, such as :

1. What kind of affixes are used to form adjective in the novel "Doctor - Nurse Encounter"?

2. How is the process of English derivational adjective in the novel "Doctor - Nurse Encounter"?

3. How the morphological process of derivational adjective in the novel " Doctor - Nurse Encounter"?

\section{CONCEPTS AND THEORETICAL FRAMEWORK \\ 2.1 Concepts}

The concepts are explained below: a. Word

Word is a free form which can stand by itself. This contrasts with a morpheme, which is the smallest unit of meaning but will not necessarily stand on its own. The term word may refer to a spoken word or to a written word.

\section{b. Derivational}

Derivational morpheme has function to form a new word either by changing the meaning of the base to which they are attached or by changing the word class. Derivation is concerned with the formation of new lexemes by affixation.

\section{c. Adjective}

Adjective is word that describes a noun, example :green in green grass (Oxford Dictionary Fourth Edition). Adjective are a large class of words that define more precisely the reference of nouns or pronouns.

d. Novel

A novel is a long written story.

\subsection{Theoretical Framework}

In this study the writer used the main theory which taken from Katamba entitled " Modern Linguistics" and McCharty entitled "An Introduction to English Morphology Word and Their Structure". Below are the explanations:

\subsubsection{Morphological Process}

An affix is a morpheme which only occurs when attached to some other morpheme or morpheme such as a root or stem or base. According to Katamba (1993: 47) affix morpheme can be divided into two major functional categories, namely derivational morpheme and inflectional morpheme. This reflect two principal word building processes inflection and derivation. Inflectional and derivational morpheme form word in different ways. Derivational morpheme form new word either by changing the meaning of the base to which they are attached or by changing the word class that a base belongs to. Suffix is the affixes attached after a root or stem or base like -ly, -er, -ing,-ish,-ed (Katamba 1993:44). Derivational morphemes are categorized into two types : class changing derivational and class maintaining derivational.

According to Katamba, derivational morpheme form new words either: 
1. By changing the meaning of the base to which they are attached, e.g. kind vs kindly ( both are adjective but which opposite meaning), obey vs disobey (both are verbs but with opposite meaning).

2. By changing the words class that a base belongs to, e.g. the addition of -ly to the adjective kind and simple produce the words kindly and simply. As a rule, it is possible to derive an adverb by adding the suffix -ly to an adjective base (Katamba,1993:47).

\subsubsection{English Derivational Adjective}

Affixation as one of the morphological process in word formation can be divided into two major functional categories, namely inflectional affixes and derivational affixes. According to McCharty (2002, 48-55) some affixes can forming adjective such as: -able, -al, -ous, -ful-ed, -ing, -y,ish, -ive, -er, -ar, -ic, -ly, -ary, -ant,-less,est,-ate,-ent,-en, un-, dis-, re-,in-.

\subsubsection{Prefix}

Prefix is an affix attached before a root or stem or base like re-,un-, and in-, dis-, in re-make, un-kind, in-accurate and dis-information. Preffixation occurs only before other morphemes. The prefix will be considered in term of class of the base to which they are added. However, the majority of prefixes can be added to base of more than one class form.

\subsubsection{Suffix}

Suffix is an affix which is placed after the stem of a word. Common examples are case endings, which indicate the grammatical case of nouns or adjectives, and verb endings, which form the conjugation of verbs. Suffixation is the part of affixation process in which a suffix is out at the en of the root to produce a new form of word. Katamba stated that the suffix is an affix which attached after the root, stem, or base like -ly,-er,-ing,-ed,- able,- al,- ous,- ful,-y,-ish,-ive,-ar,- ic,- ary, -ant,-less,-est,-ate,-ent,-en.

\section{RESARCH METHOD 3.1 Data Source}

The data in this writing are derived adjective from the sentences that contain derived adjective found in novel " A Doctor - Nurse Encounter" by Carol Ericson.
It published by Harlequin Mills \& Boon on 2008. The novel consists of 211 pages. The reason of choosing this data source, because a lot of derived adjective can be found in this novel which absolutely supports the analysis in this writing.

\subsection{Data Collection}

Data collection is a process of how the data are collected from the data source. The method of collecting data in this study is observation method. Observation means that the action of research by reading the data source. The data will be taken by following some steps. Firstly, read and reread the novel "A Doctor - Nurse Encounter" carefully to get the affixes derived adjective from the word used. Secondly, identifying, classifying the data underlining the words which use derivational affixes into a group of form based on the theory.

\subsection{Data analysis}

The collected data were analyzed descriptively by using the theory of Derivational Adjective purposed by Katamba (1993) to analyzed how the process of derivational adjective and McCharty (2002) to analyzed kinds of derivational adjective as found in novel. The main purposed is to identify and describe the word classes which are derived into adjective by derivational affixes attached on the word use in novel " A Doctor - Nurse Encounter".

\subsection{Finding Presentation}

This research were use formal and informal method. Formal method uses a table to count English derived adjective in novel " A Doctor - Nurse Encounter" and use the symbols "+" means add to suffix and prefix and " "means to become. And informal method, this method means that the data of this study will be analyzed descriptively.

\section{FINDING AND DISCUSSION 4.1 Finding}

There are a lot of affix derived adjective in the novel "A Doctor - Nurse Encounter" that not explain yet. There were 21 derivational adjective found, 18 words were found from suffix, meanwhile 3 words were found from the prefix.

\subsection{Discussion}


In this research which discussed about the kinds and the process of English derivational adjective, the writer found 21 types of derivational adjective which are the derivational prefixes and derivational suffixes.

There were twenty - one affixes derived adjective found in the novel " A Doctor - Nurse Encounter". The kinds and the processes of attachment affixes can be forming adjective as mentioned below.

\section{Dis -}

She spread her arms to encompass the dishelved bedroom. (page.47)

$$
\begin{array}{ll}
\text { Shelve(v) + -ed } & \text { shelved(adj.) } \\
\text { Dis- + shelved(adj.) } & \text { dishelved(adj.) }
\end{array}
$$

In forming the word dishelved there are two processes of derivational affixation. The first one change shelve belong to verb becomes shelved belongs to adjective. And the second process is adding dis- to shelved which make the changing of meaning becomes not, eventhough they are in the same word class.

\section{2. -ing}

"you're the one juggling electronic devices. Why don't you.... (page.8)

$$
\text { Juggle(V1) + -ing juggling(adj.) }
$$

The derivational suffix -ing is used in word juggling. It changes the word class form verb into adjective. The verb juggling becomes adjectives because juggling electronic devices is one phares and the word juggling has the function to modify the word electronic and device.

3. -al

.... A monster with a criminal family, a violent background and half life of secrets and lies.(page.!44)

$$
\text { Crime(n) + -al criminal(adj.) }
$$

The word shows that criminal is derived from the word crime because attached by suffix -al. the adjective criminal has meaning as concerning crime.

$$
\begin{aligned}
& \text { 4. -ate } \\
& \text { "My brother is very affectionate". } \\
& \text { (page.79) } \\
& \text { Affect(v) + -ion affection(n) } \\
& \text { Affection + -ate affectionate(adj.) }
\end{aligned}
$$

There are two derivational affixation processes occur in word affectionate. In the first process, the suffix -ion is attached to affect that belongs to verb and becomes affection that belongs to noun. And the second process is affection that belongs to noun becomes affectionate because of an attachment -ate.

5. -ary

He'd built a thriving practice, innovated a few revolutionary cosmetic surgery technicques.. (page.81).

$\mathrm{Re}-+$ evolution(n) revolution(n) adj.)

Revolution(n) + -ary revolutionary(-

The word revolutionary is categorized as adjective that has two derivational affixiation processes. The prefix re- is attached to evolution that belongs to noun and changes into revolution that belongs to adjective either but has different meaning. Then the suffix -ary attached to revolution and cause the word class changing from noun into adjective.

\section{CONCLUTION}

Based on the analysis and the discussion, it can be concluded that derivational morpheme has function to form a new word either by changing the meaning of the base to which they are attached or by changing the word class. There are nineteen affixes derived adjective in novel"A Doctor - Nurse Encounter" three prefixes and eighteen suffixes. Derivational prefixes form new words by both maintaining and changing its grammatical category, prefixes in novel are un-, dis-, non-. the derivational suffixes cause a major grammatical category, involving moving the base form one word class into another, in the other cases, the change by derivational suffix may be minor, derivational suffixes in novel are able, -al, - ous,- ful, -ed, -ing, -y, -ish, -ive, -ly, -ary, -less, -est, -ent, -en, -ar, -er,-ic. The most dominant affixes derived adjective found in the novel " A Doctor - Nurse Encounter " is suffixes -ed which reaches 67 numbers.

The affixes mentioned above can change the grammatical and the meaning of words when they are attached. The process of English derivational adjective can be analyzed by allying the flat structure because it can give a clearer understanding of the analyzed data. Most of the words found in the novel " A Doctor - Nurse Encounter". 


\section{BIBLIOGRAPHY}

Aitchison, Jane. 1978. Teach Yourself Linguistic. Great Britain: Hodder and Stoughton.

Bauer,L. 1983. English Word Formation. Cambrigde:CUP.

Bull, Victory. 2008. Oxford Learners Pocket Dictionary Fourth Edition. New York: Oxford University Press.

Carstairs, Andrew and McCharty, 2002.An Introduction to English Morphology Word and Their Structure. British: Edinburgh University Press.
Katamba, Francis. 1993. Modern Linguistics : Morphology. Great Britain: Macmillan Press Ltd.

Ouick, Randolph and Sidney Greenbaum,1973. A University Grammar of English. London:Longman Group Limited.

Wells, H.G. 1911. The Door in the Wall. Tokyo: Nan' un -do Contemporary Library.

Wellek, Rene and Austin Warren. 1956. Theory of Literature Third Edition. New York :A Harvest Book Harcourt,Brace and World,Inc. 